\title{
The Role of Gender Diversity on Tax Aggressiveness and Corporate Social Responsibility: Evidence from Italian Listed Companies
}

\author{
Andrea Vacca ${ }^{1}$, Antonio Iazzi ${ }^{1, *(\mathbb{D})}$, Demetris Vrontis ${ }^{2}\left(\mathbb{D}\right.$ and Monica Fait ${ }^{1}$ (i) \\ 1 Department of Management, Economics, Mathematics and Statistics, University of Salento, 73100 Lecce, \\ Italy; andrea.vacca@unisalento.it (A.V.); monica.fait@unisalento.it (M.F.) \\ 2 Department of Marketing, School of Business, University of Nicosia, 2417 Nicosia, Cyprus; \\ vrontis.d@unic.ac.cy \\ * Correspondence: antonio.iazzi@unisalento.it
}

Received: 13 February 2020; Accepted: 3 March 2020; Published: 5 March 2020

check for updates

\begin{abstract}
The paper aims to examine the moderating role of gender diversity within a corporate board on the relationship between tax aggressiveness and a firm's corporate social responsibility (CSR) approach. This analysis was conducted using a set of indicators of financial statements of 168 Italian listed firms between 2011 and 2018. In addition, the sustainability reports of the same companies were observed. To perform the analysis a logit regression model is used. This paper shows different empirical results. First, this study notes that there is not a direct relationship between tax aggressiveness and CSR reporting. Second, gender diversity in a board of directors increases the orientation of companies to CSR disclosure, but does not have an impact on the relationship between tax aggressiveness and CSR disclosure. Instead, CEO gender has a positive influence on the relationship between corporate tax planning and CSR reporting in accordance with Global Reporting Initiative (GRI) standards. This study emphasizes the key role of gender diversity in the growth of the CSR approach and the reputation of companies. Therefore, governments and policymakers of major countries should promote gender diversity in corporate decision-making bodies, which contributes to achieving the Sustainable Development Goals (SDGs).
\end{abstract}

Keywords: gender diversity; tax aggressiveness; corporate social responsibility

\section{Introduction}

In recent years, there has been an increase in the number of studies [1-3] on the effects of the adoption of corporate tax planning within the business environment. A tax planning strategy or tax aggressiveness is a managerial strategy adopted by a company to reduce its tax burdens and, as a consequence, to minimize its tax liability in compliance with the country framework [4]. According to Lanis and Richardson [5], these strategies are becoming common features within the business environment, as taxes represent a critical factor in the decision-making process of a company.

Specifically, the debate that attracted the attention of many scholars is focused on the study of a tax strategy as part of corporate social responsibility (CSR) [1,6,7].

CSR is "a concept whereby companies integrate social and environmental concerns in their business operations and in their interaction with their stakeholders on a voluntary basis" [8]. The engagement in the long-term by a firm on these ethical practices is a critical factor in its survival and success [9-11].

Tax aggressiveness and CSR are related, as taxes have a central role in the management of a company, but they also have effects on the welfare of society. The fewer resources the state takes, the fewer services it can provide [12-14]. Consequently, this strategy can generate negative effects on the corporate reputation [15]. 
The strategies are planned by the board of directors, which is an expression of a company's values [16]. Some authors argue that women have more ethical values than men and their presence on a board of directors reduces the tax planning strategies $[17,18]$ and increases CSR approach and disclosure $[19,20]$.

In recent years, and because of several corporate scandals, governments and policymakers of major countries are promoting the representation of women on decision-making bodies of firms.

Specifically, the European Commission, with directive 2012/0299/EC, started to support long-term gender diversity within a listed firm's governance structure, including making boards of directors up to $40 \%$ women [21]. Additionally, the United Nations approved Agenda 2030 in September 2015 for sustainable development, a document made up of 17 Sustainable Development Goals (SDGs) and 169 sub-targets for combating poverty, climate change, and social and economic inequality. In particular, one of these sustainable goals, SDG 5, aims to reach gender equality, and sub-target 5.5 promotes the equality and the participation of women in the political and managerial decision-making processes of governments and firms [22].

According to these arguments, this work has two objectives. The first is to observe the relationship between the adoption of tax planning and a firm's CSR approach. To analyze the CSR approach, this research considers CSR reporting in accordance with Global Reporting Initiative (GRI) standards, as these standards are used by firms to communicate the impact of their activities on the economy, environment, and society.

The second objective, in light of Agenda 2030, is to analyze the moderating role of gender diversity within corporate boards on the relationship between tax aggressiveness and CSR disclosure. Specifically, this research tries to note whether tax aggressive firms' approach to CSR disclosure is affected by the presence of female directors and female CEOs within their decision-making bodies.

Related to the moderating role of the composition of a corporate board on the relationship between CSR and tax aggressiveness, Lanis and Richardson [2] show that the presence of independent directors within the corporate decision-making body improves the relationship between CSR performance and tax aggressiveness. This work continues this recent innovation and it tries to close the gap in the existing literature, analyzing the moderating roles of gender diversity within boards of directors and CEO gender on the relationship between tax aggressiveness and CSR disclosure in accordance with GRI standards. The choice was to study gender diversity as part of a corporate board's structure, as the involvement of female directors in the decision-making process could represent a firm's CSR approach [23] and an important factor for its economic success [24].

Additionally, recent empirical studies $[17,18]$ showed that female directors' engagement in the decision-making process influences the adoption of corporate tax planning.

The work is organized as follows. Firstly, according to a literature review on the topic, the research hypotheses are defined. In the second section, the research methodology is explained, and the results of the regression models are then presented and discussed. Finally, conclusions are given in light of the limitations and possible additional lines of research.

\section{The Impact of Corporate Tax Planning on Corporate Social Responsibility}

A tax planning strategy is a practice adopted by a firm to reduce its tax burden in compliance with the country framework. This practice allows a firm to ensure adequate remuneration for its shareholders [25-27] and/or increase the availability of resources to invest in creating value [28]. This strategy is also risky; it entails consequences for a company, such as the cost of complying with tax administration [29] and reputational costs resulting from social and political pressure on corporate decisions [15].

The reputational costs linked to corporate tax strategy are due to the negative effects on the community, as the government has fewer resources to provide services to citizens [13,30,31], generating consequences for the community such as social inequality and a slowdown in economic growth $[32,33]$. 
An aggressive tax strategy is not a socially responsible practice [34]. The literature highlights different results regarding the possible relationship between tax aggressiveness and CSR.

Engagement in CSR practices proved to be a pivotal factor in the survival and success of a firm [16]. CSR represents a company's commitment to contribute to economic development and to improve social and environmental standards within the European Union and at the international level [35]. The adoption of these ethical practices depends on managers' values and reasons [36]; they are adopted by firms to solve the agency problems between shareholders and managers [37] and to improve the relationship with stakeholders [38].

Previous studies showed that the involvement of CSR issues in corporate decision-making process have important effects within the business environment. Indeed, the adoption of these ethical practices enables a company to reach legitimacy [39], high financial results [40], and high level of transparency [41] and improves a corporate's reputation [42].

In this research, a firm's CSR approach is evaluated by CSR reporting and its compliance with the standards of GRI. CSR reporting is one of the many tools used by a firm to acquire legitimacy through better relationships with stakeholders and to improve its reputation [43] to guarantee its survival and to avoid corporate scandal [44].

Some authors $[33,45,46]$ argue that tax-aggressive firms are more oriented to a CSR approach. Hoi et al. [34] argue that firms pay taxes as a CSR activity to improve their corporate reputations and to reduce compliance costs from the relationship with tax administration.

Some studies [26,34,47-49] highlight that a high level of CSR performance is associated negatively with corporate tax planning.

However, Lanis and Richardson [50] compare firms that are tax aggressive and those that are not aggressive and they find a positive relationship between CSR disclosure and tax aggressiveness. In the same way, Gulzar et al. [51] find that a tax strategy is related positively to CSR disclosure.

Based on these arguments, the level of a firm's CSR disclosure in accordance with GRI standards could be influenced by the adoption of corporate tax planning, and therefore, our research hypotheses include the following.

Hypothesis 1 (H1): The adoption of corporate tax planning influences the CSR approach.

The Moderating Role of the Board of Directors' Gender on the Relationship between Tax Aggressiveness and CSR

The board of directors decides the corporate strategies to be adopted and defines the level of disclosure of the results achieved. The corporate board is made up of several directors characterized by different experiences, values, and skills. Therefore, each member could have a different evaluation of the corporate risk, affecting the strategy and CSR reporting [16]. Recently, there was an increase in studies on the composition of the board of directors. Specifically, some studies [52-54] analyzed the role of gender leadership and board gender in the decision-making body of a firm.

This area of literature shows that gender diversity is relevant to the decision-making process of a firm; it enables a company to achieve a good governance structure [55], ethical and strategic decision-making processes [56], economic and financial efficiency [57], and more transparency [58]. This allows the board of directors to plan the firm's strategy, taking into account the interests of several groups of stakeholders [59] with the consequence of reputational growth and high financial performance $[19,52,54]$.

In relation to the influence of women on the decision-making process of adopting a tax strategy, Kastlunger et al. [17] and Lanis et al. [18] argue that women on the board of directors do not engage in tax planning activities. They attribute more ethical values to female than to male directors, which indicates that men have a better attitude to influence the decision-making process of adopting a tax strategy. In contrast, Khaoula et al. [60] do not show any significant relationship between gender diversity in a corporate board and the decision-making process in adopting a tax strategy. 
On the role of gender diversity on CSR disclosure, some authors $[19,20,23,56]$ argue that gender diversity of a board has a positive impact on CSR activities and CSR reporting, with the consequence of improving the corporation's reputation and its relationship with several groups of stakeholders.

On the contrary, Khan [61] does not find any significant influence of gender diversity within the board of directors and the attitude of a firm to disclosing its CSR activities.

Pertaining to gender leadership, Khan [62] shows a positive relation between a firm's performance and the role of a female CEO. In contrast, Lam et al. [63] and Dezsö et al. [64] do not show any significant empirical results related to this characteristic of the CEO.

Pertaining to the previous arguments on the ethical values attributed to women, some sources [43,65-67] show a positive relationship between a CEO's gender and the firm's CSR engagement.

Regarding the influence of a CEO's gender on the adoption of corporate tax planning, the literature did not analyze CEO's gender as a critical factor in the decision-making process.

Based on this, we can expect a moderating effect by the level of gender diversity within a board of directors and by the CEO's gender on the relationship between tax aggressiveness and CSR disclosure in accordance with GRI standards. Therefore, we can develop the following research hypotheses.

Hypothesis 2a (H2a): The presence of female directors on a corporate board influences the relationship between tax aggressiveness and the CSR approach.

Hypothesis $\mathbf{2 b}(\mathbf{H} \mathbf{2 b})$ : The presence of a CEO woman on a corporate board influences the relationship between tax aggressiveness and the CSR approach.

\section{Data and Research Methodology}

The population under investigation was made up of 168 listed firms on the Milano Stock Exchange that were not in the finance industry; it was extracted from the "AIDA Bureau Van Dijk" database with the search criteria of firms that hold shares in at least one foreign subsidiary in countries other than Italy in the 2018 fiscal year (see Table 1).

Table 1. Description of the population.

\begin{tabular}{ccc}
\hline Sector & $\mathbf{N}$ & $\%$ \\
\hline Artistic, sports, entertainment, and fun activities & 1 & $0.60 \%$ \\
Activities of accommodation and catering services & 1 & $0.60 \%$ \\
Real estate activities & 5 & $2.98 \%$ \\
Manufacturing activities & 66 & $39.29 \%$ \\
Professional, scientific, and technical activities & 34 & $20.24 \%$ \\
Wholesale and retail trade, repair of motor vehicles and motorcycles & 22 & $13.10 \%$ \\
Buildings & 4 & $2.38 \%$ \\
Water supply, sewerage networks, waste management activities, and recovery & 2 & $1.19 \%$ \\
Electricity, gas, steam, and air conditioning supply & 8 & $4.76 \%$ \\
Rental, travel agencies, business support services & 3 & $1.79 \%$ \\
Information and communication services & 17 & $10.12 \%$ \\
Transport and storage & 5 & $2.98 \%$ \\
Total & 168 & $100 \%$ \\
\hline
\end{tabular}

To achieve the aims of the research, this work used two different consequential research methodologies.

First of all, a document analysis approach was used to collect information on the presence of female directors within a corporate board. This research method is based on the evaluation of public documents characterized by stability and exactness of the data [68]. In this case, to collect gender diversity's attributes, the annual reports published by listed firms on their websites were assessed. It was possible to use the document analysis, as Italian listed firms are required by Italian legislation 
(art. 123-bis del D. Lgs n. 58/98) to disclose in their annual report the attributes of the board's structure and institutional ownership.

Finally, to analyze the moderating role of gender diversity on the relationship between tax aggressiveness and CSR disclosure, this work used a panel data analysis with fixed effects [69] on a time interval of seven years (2011-2018), with the determination of 1176 observations.

A panel data analysis method was conducted, as the Italian Stock Exchange has a different approach from other countries' stock exchanges to corporate governance and corporate board compositions. Indeed, the Italian context is made up of listed firms characterized by an ownership structure made up of few subjects, such as family firms which present a rigidity in the changes of the ownership structure and the composition of the boards of directors [70,71]. Therefore, to understand the phenomenon, it was necessary to study each unit at the medium and long-term intervals.

\section{Models and Variables}

To achieve the aims of this research, two different logit regression models were estimated.

Model 1:

$$
C S R D_{i t}=\alpha_{i t}+\beta_{1 t} S_{I Z E T_{i}}+\beta_{2 t} L E V+\beta_{3 t} R O A+\beta_{4 t} S I Z E B+\beta_{5 t} T A+\beta_{6 t} \% W O M+\beta_{7 t} C E O W
$$

Model 1 aimed to detect the influence of corporate tax planning on CSR reporting in accordance with GRI standards.

Model 2:

$$
\begin{gathered}
\operatorname{CSRD}_{i t}=\alpha_{i t}+\beta_{1 t} \operatorname{SIZET}_{i}+\beta_{2 t} L E V+\beta_{3 t} R O A+\beta_{4 t} S I Z E B+\beta_{5 t} T A+\beta_{6 t} \% W O M \\
+\beta_{7 t} C E O W+\beta_{8 t} \% W O M \times T A+\beta_{9 t} C E O W \times T A
\end{gathered}
$$

Model 2 was developed adding the variables \%WOM X TA, CEOW X TA. It aimed to study the moderating role of gender diversity on the relationship between tax aggressiveness and CSR reporting in accordance with GRI standards.

Based on the previous arguments, the logit regression models of this research are made up of variables widely used in previous studies on corporate governance, CSR disclosure, and tax aggressiveness.

The choice of the logit regression model is motivated by the binary nature of the dependent variable CSRD as a measure of CSR disclosure in accordance with GRI standards. This variable is a dummy variable that takes a value of 1 or 0 , in which it takes a value of 1 if a firm provides its CSR report in accordance with GRI standards, otherwise it takes a 0 value. The GRI database was checked to detect whether a firm respects the GRI standard in its sustainability report (see Table 2).

According to previous studies, this work uses control variables with characteristics of a firm and attributes of a corporate board.

SIZET is the variable that represents the size of a firm, and it is measured by the natural logarithm of total asset. Gul et al. [72] and Artiach et al. [73] argue that large firms are most likely to engage in CSR activities and to disclose the impact of their activities on the stakeholder.

$R O A$ is the variable measuring the profitability index of return on assets. It is calculated by the ratio of net profit to the total asset. Previous studies show contradictory empirical results. Some sources [61,74] show a positive relationship between profitability and CSR reporting. In contrast, others $[75,76]$ argue that a firm's profitability is negatively associated with the level of a firm's CSR disclosure.

$L E V$ represents the level of indebtedness of a firm measured by the ratio between the book value of total debts and equity. Recent empirical studies show a positive relationship between CSR reporting and leverage. Specifically, Clarkson et al. [77] and Bouten et al. [78] argue that firms with a high level of leverage are most likely to engage in CSR activities to reduce agency costs. 
SIZEB represents the size of the board of directors. It is measured by the natural logarithm of the number of board members. Darus et al. [79] show a positive relation between the size of the board of directors and CSR disclosure.

$T A$ represents "effective tax rate" (ETR) as a measure of corporate tax planning. This variable is calculated by the ratio between total tax expense and accounting income before taxes [80-83]. It is the measure of tax aggressiveness used by more scholars [80,82]. Low levels of ETR could mean a firm's adoption of a tax strategy. The engagement of a firm in tax planning influences the effective tax rate because of particular transactions, tax credits, and operations abroad to offset the tax burden. These practices enable a company to reduce its taxable income and simultaneously to reduce its ETR.

$\%$ WOM represents the percentage of women directors on the board. This variable is calculated through the ratio between the number of women on the board and the size of the board.

CEOW represents the CEO's gender. It is a dummy variable that takes a value of 1 or 0 . We give it a value of 1 if the role of the CEO is held by a woman; otherwise, the variable takes a value of 0 .

The independent variables are the measures of the moderating effect of the level of gender diversity within the board on the relationship between tax planning and CSR reporting.

$\% W O M \times T A$ measures the interaction effect between the percentage of female directors on the board and tax aggressiveness, calculated by the multiplication between \%WOM and TA.

CEOW X TA measures the interaction effect between the role of CEO held by a woman and tax aggressiveness, computed by multiplying CEOW and TA.

Table 2. Description of the variables.

\begin{tabular}{ccc}
\hline Code & Variable & Value \\
\hline CSRD & CSR reporting & $1=$ accordance to GRI \\
SIZET & Total asset & $0=$ no accordance to GRI \\
$L E V$ & Leverage & Log \\
$R O A$ & Return on asset & $\%$ \\
SIZEB & Number of directors & Log \\
TA & Measure of tax aggressiveness of a firm & $\%$ \\
$\% W O M$ & Percentage of female directors & $\%$ \\
CEOW & CEO gender & $1=$ female \\
& & $0=$ male \\
\hline
\end{tabular}

\section{Empirical Results}

\subsection{Descriptive Statistics}

Table 3 reports on the results of the descriptive statistical analysis of the variables under investigation.

The results reported in Table 3 show a mean value of the effective tax rate (TA) equal to 11.60, lower than the Italian tax rate of $27.9 \%$. The Italian tax rate of $27.9 \%$ takes into account the tax rate of $24 \%$ of the corporate income tax (IRES) and the tax rate of $3.9 \%$ of the regional production tax (IRAP).

Regarding board gender ( $\% W O M)$, the analysis shows an average percentage of $23.08 \%$ women directors and a maximum percentage equal to $57.14 \%$ on the board. Additionally, the data show that firms that do not have any female board members are under investigation.

Related to gender leadership, the results show a mean value of 0.074 that is attributed to the variable $C E O W$. These data show that listed firms under investigation mainly entrust the role of CEO to a man. 
Table 3. Descriptive statistics based on 168 Italian listed firms.

\begin{tabular}{|c|c|c|c|c|c|c|}
\hline Variable & Description & Mean & Median & Min & Max & St. Dev. \\
\hline CSRD & CSR reporting in accordance with GRI & 0.139 & 0 & 0 & 1 & 0.362 \\
\hline SIZET & Natural logarithm of total asset & 5.254 & 5.454 & 0 & 7.953 & 1.434 \\
\hline$L E V$ & $\begin{array}{c}\text { Leverage } \\
\text { (Book value of debts/Equity) }\end{array}$ & 0.581 & 0.330 & -23.93 & 24.30 & 1.619 \\
\hline$R O A$ & $\begin{array}{l}\text { Return on assets } \\
\text { (Net profit/Total assets) }\end{array}$ & 0.882 & 0 & -114.11 & 297.56 & 12.24 \\
\hline SIZEB & $\begin{array}{l}\text { Number of directors } \\
\text { Effective Tax Rate }\end{array}$ & 9.057 & 9 & 1 & 22 & 3.025 \\
\hline$T A$ & $\begin{array}{c}\text { (Total tax expense/Accounting income } \\
\text { before tax) }\end{array}$ & 11.60 & 0 & 0 & 96.44 & 17.28 \\
\hline$\% W O M$ & Percentage of female directors & 23.08 & 2 & 0 & 57.14 & 13.53 \\
\hline CEOW & CEO is a woman & 0.074 & 0 & 0 & 1 & 0.263 \\
\hline
\end{tabular}

\subsection{Pearson's Correlation Analysis}

Table 4 shows the results of Pearson correlation analysis. The data show that size of a firm (SIZET) and corporate board's size (SIZEB) are positively correlated with CSR disclosure.

The absence of a correlation greater than 0.800 excludes the presence of multicollinearity between the variables $[66,76]$. Related to the influence of gender diversity on CSR disclosure, the analysis shows that board gender (\%WOM) positively affects the adoption of a CSR report in accordance with GRI guidelines, conversely, CEO gender (CEOW) does not influence CSR disclosure.

Moreover, the analysis provides evidences that the adoption of a tax planning by a firm is not correlated with CSR disclosure in accordance with GRI standards. In the same way, the results show that high levels of corporate tax aggressiveness (TA) are negatively correlated with firm's size (SIZET), leverage $(L E V)$, return on assets $(R O A)$, and positively correlated with size of board of directors. Pertaining to the influence of gender diversity on tax aggressiveness, the correlation analysis shows that the presence of female directors $(\% W O M)$ within corporate board has a positive influence on decision-making process of a firm to adopt a tax strategy. In contrast, the correlation analysis notes that gender leadership such as the role of CEO covered by a woman (CEOW) does not influence the level of corporate tax aggressiveness.

Table 4. Pearson's correlation analysis results based on 168 Italian listed firms.

\begin{tabular}{|c|c|c|c|c|c|c|c|c|}
\hline & (1) & (2) & (3) & (4) & (5) & (6) & (7) & (8) \\
\hline (1) CSRD & 1 & & & & & & & \\
\hline (2) SIZET & $0.336^{* *}$ & 1 & & & & & & \\
\hline (3) LEV & 0.003 & $0.099^{* *}$ & 1 & & & & & \\
\hline (4) $\mathrm{ROA}$ & 0.004 & $0.076^{* *}$ & 0.039 & 1 & & & & \\
\hline (5) SIZEB & $0.314^{* *}$ & $0.334^{* *}$ & -0.044 & 0.045 & 1 & & & \\
\hline (6) $\mathrm{TA}$ & -0.053 & $0.085^{* *}$ & $0.108^{* *}$ & $0.288^{* *}$ & $-0.153^{* *}$ & 1 & & \\
\hline (7) $\% W O M$ & $0.086^{* *}$ & 0.035 & -0.030 & -0.029 & $0.144^{* *}$ & $-0.085^{* *}$ & 1 & \\
\hline (8) CEOW & 0.011 & -0.004 & -0.005 & -0.026 & -0.001 & -0.047 & $0.077^{* *}$ & 1 \\
\hline
\end{tabular}

\subsection{Regression Analysis Results}

The analysis based on the logit regression models shows interesting empirical results reported in Table 5 and Figure 1.

The results of Model 1 show that there is not a significant relationship between the adoption of tax planning by a firm and CSR reporting in accordance with GRI standards; thus, Hypothesis 1 is rejected. This finding is in contrast with the previous studies of Lanis and Richardson [50] and Gulzar et al. [51]. These data suggest that a tax-aggressive firm is likely less oriented to adopt a multi-stakeholder 
approach to improving corporate relationships with both internal stakeholders, such as shareholders, and external stakeholders, such as community. This could mean that in several cases the firm's tax approach is not aligned with its commercial interests and an accurate disclosure of its concerns about CSR issues could lead to reputational costs.

Table 5. Results of the regression model based on 168 Italian Listed firms.

\begin{tabular}{|c|c|c|c|c|}
\hline & \multicolumn{2}{|c|}{ Model 1} & \multicolumn{2}{|c|}{ Model 2} \\
\hline & \multicolumn{2}{|c|}{ CSRD } & \multicolumn{2}{|c|}{ CSRD } \\
\hline & Coeff. & Sig. & Coeff. & Sig. \\
\hline const & 0.1886 & ** & 0.1648 & $* *$ \\
\hline SIZET & -0.0114 & $* *$ & -0.0117 & $* *$ \\
\hline LEV & -0.0029 & & 0.0033 & \\
\hline ROA & -0.0002 & & -0.0002 & \\
\hline SIZEB & 0.0233 & & 0.0530 & \\
\hline TA & 0.0001 & & 3.9171 & \\
\hline$\% W O M$ & 0.0014 & $* * *$ & 0.0012 & $* *$ \\
\hline CEOW & 0.0557 & & 0.0885 & \\
\hline$\% W O M \times T A$ & & & 1.7115 & \\
\hline CEOW X TA & & & -0.0059 & $* * *$ \\
\hline $\mathrm{R}^{2}$ & \multicolumn{2}{|c|}{0.8321} & \multicolumn{2}{|c|}{0.8339} \\
\hline Type of Panel & \multicolumn{2}{|c|}{ Fixed Effects } & \multicolumn{2}{|c|}{ Fixed Effects } \\
\hline Number of observations & \multicolumn{2}{|c|}{1176} & \multicolumn{2}{|c|}{1176} \\
\hline
\end{tabular}

Furthermore, the results of Model 2 show that the relationship between tax aggressiveness and CSR reporting becomes significant with the presence of a CEO woman (CEOW) on the corporate board (Figure 1), and, thus, Hypothesis $2 \mathrm{~b}$ is accepted. Specifically, a CEO who is a woman has a positive influence on the CSR approach of a tax-aggressive firm. These data note that gender leadership could be a critical factor within a governance structure of a firm to guarantee its legitimacy within the business environment. Precisely, a female CEO increases the engagement of a firm on CSR practices, improving reputation and reducing the costs associated with the engagement in a tax strategy. In contrast, this research shows that the presence of female directors on the corporate board does not affect the relationship between corporate tax planning and CSR reporting (Figure 1); thus, Hypothesis $2 \mathrm{a}$ is rejected.

Additionally, the analysis of Model 1 shows other interesting empirical results on the involvement of gender diversity within a corporate decision-making process. Specifically, the results of Model 1 reveal a positive relationship between the presence of women directors on a corporate board and CSR disclosure (Figure 1). These data confirm the ethical values attributed to gender diversity within the corporate board in disclosing the impact of corporate activities on CSR issues, and it is consistent with previous studies of Rao and Tilt [23] and Amorelli et al. [20]. In contrast, pertaining to gender leadership, the analysis of Model 1 does not show a significant relationship between the presence of a female CEO and CSR reporting (Figure 1). This result is consistent with Dezsö [64].

Regarding control variables, the analysis shows that \%WOM and CEOW are positively associated with CSR disclosure, simultaneously, this study notes that SIZET impacts negatively on CSR reporting.

To assess the reliability of the analysis, a robustness test was performed. According to prior methodological studies in the business and management field, the adoption of additional analysis in order to check the reliability of the findings represents an effective strategy in order to increase the overall rigor of the research $[83,84]$.

The robustness check was performed through the use of a logistic regression model considering the independent variable $T A$ as a dummy variable that takes value 1 or 0 . This research considers a firm to be tax aggressive and the variable TA takes a value of 1 if the firm has an ETR value lower than the Italian tax rate of $27.9 \%$; otherwise, the variable $T A$ takes a value of 0 . The choice to use a logistic 
model for a robustness check was based on evidence in prior studies on strategic management $[85,86]$. The results of the robustness check (Table 6) confirm the reliability of the analysis. Specifically, this analysis confirms the results related to the regression variables $T A, \% W O M$, and CEOW X TA, as reported in Table 5.

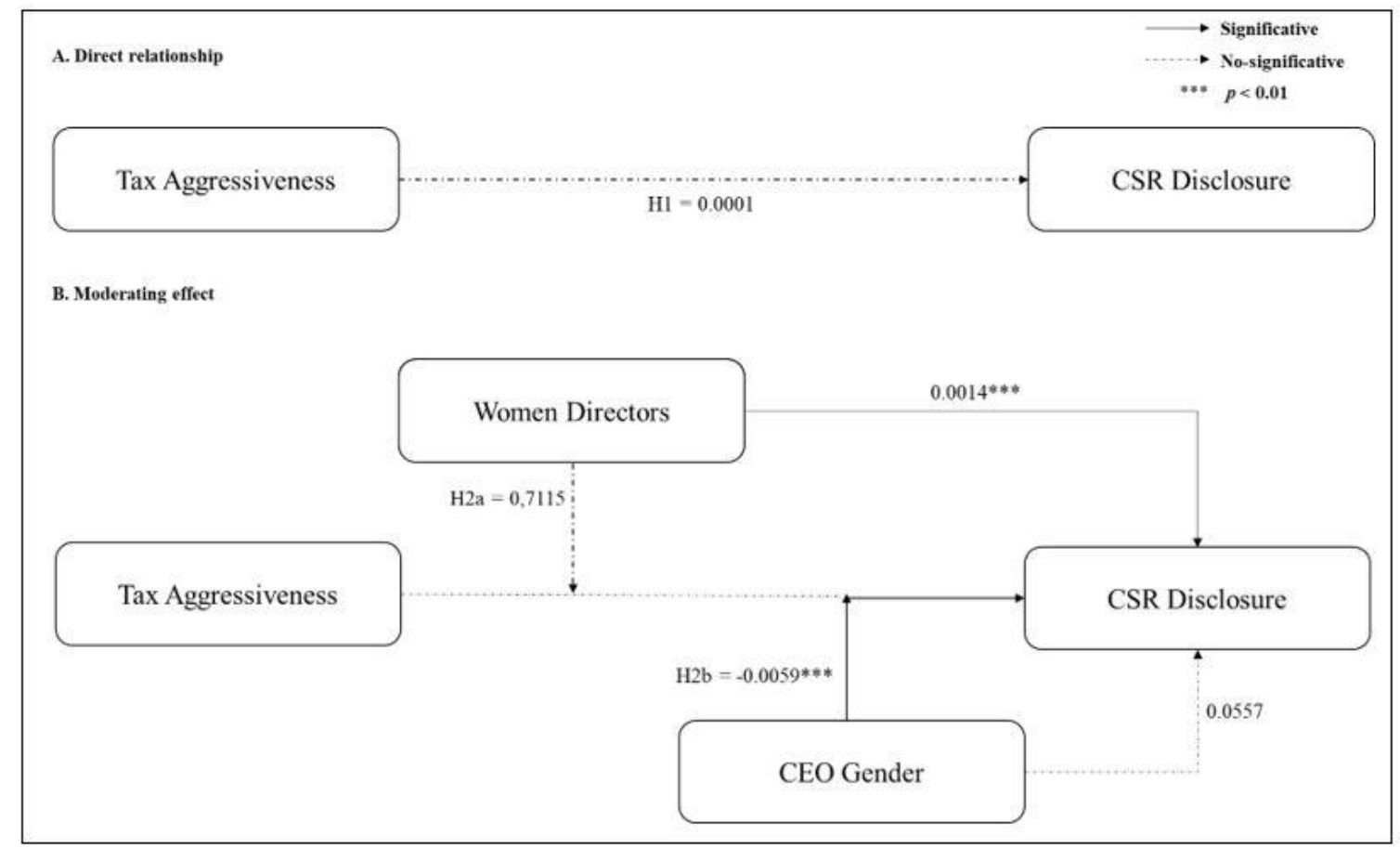

Figure 1. Framework of empirical model results based on 168 Italian listed firms.

Table 6. Results of robustness test based on 168 Italian listed firms.

\begin{tabular}{|c|c|c|c|c|}
\hline & \multicolumn{2}{|c|}{ Model 1} & \multicolumn{2}{|c|}{ Model 2} \\
\hline & \multicolumn{2}{|c|}{ CSRD } & \multicolumn{2}{|c|}{ CSRD } \\
\hline & Coeff. & Sig. & Coeff. & Sig. \\
\hline const & 0.1773 & ** & 0.1554 & ** \\
\hline SIZET & -0.0106 & ** & -0.0111 & $* *$ \\
\hline LEV & -0.0031 & & 0.0044 & \\
\hline ROA & -0.0001 & & -0.0001 & \\
\hline SIZEB & 0.0137 & & 0.0557 & \\
\hline TA & 0.0213 & & 0.0035 & \\
\hline$\% W O M$ & 0.0014 & $* * *$ & 0.0013 & \\
\hline CEOW & 0.0561 & & -0.1593 & ** \\
\hline$\% W O M \times$ TA & & & 0.0001 & \\
\hline CEOW X TA & & & 0.2389 & $* * *$ \\
\hline $\mathrm{R} 2$ & \multicolumn{2}{|c|}{0.8324} & \multicolumn{2}{|c|}{0.8346} \\
\hline Type of Panel & \multicolumn{2}{|c|}{ Fixed Effects } & \multicolumn{2}{|c|}{ Fixed Effects } \\
\hline Number of observations & \multicolumn{2}{|c|}{1176} & \multicolumn{2}{|c|}{1176} \\
\hline
\end{tabular}

\section{Contributions and Conclusions}

In line with the United Nations' [22] Agenda 2030 and SDG 5 and its sub-target 5.5 in particular, this study enriches the debate on the role of gender diversity within the business environment, showing how gender diversity could cover a key role within the governance structure of a firm. Specifically, this research aimed to analyze the moderating role of board of directors' gender and gender 
leadership on the relationship between tax aggressiveness and CSR disclosure, providing different theoretical contributions.

First, this work extends previous literature [50,51] on the relationship between corporate tax aggressiveness and CSR disclosure, showing that the adoption of corporate tax planning does not have a direct influence on a firm's CSR reporting in accordance with GRI standards (Figure 1). This result suggests that the effects of a firm being tax aggressive could not allow it to publish accurate information of its concerns about CSR issues while trying to safeguard its legitimacy within the business environment.

Second, this study improves understanding of the moderating role of board of directors' characteristics on the relationship between tax aggressiveness and CSR. Prior studies [2] showed that the involvement of outside directors on the corporate board improves the relationship between CSR performances and tax aggressiveness. This study closes a gap in the literature, analyzing the influence of gender diversity and gender leadership in corporate board. Specifically, this paper provides evidence that the presence of women directors on corporate decision-making bodies does not affect the relationship between tax aggressiveness and CSR disclosure (Figure 1). Conversely, women who hold the role of the CEO have a positive influence on the relationship between tax aggressiveness and CSR disclosure (Figure 1). These data suggest that in a tax-aggressive firm, a female CEO increases the commitment to CSR activities and to their communication to improve the firm's reputation.

In addition to the theoretical contributions, this work also provides practical implications.

First, this study helps investors, entrepreneurs, and the community to understand direct and indirect connections between the influence of each player who is responsible for the corporate decision-making process on the strategy adopted, as well as for a firm's sustainability and financial results.

Specifically, the appointment of a woman to the position of CEO could allow a firm to reduce the reputational cost related to the engagement of corporate tax planning by accurately disclosing CSR activity in accordance with GRI standards. This allows a firm to adopt a multi-stakeholder approach to improving corporate relationships with both internal stakeholders, such as shareholders, and external stakeholders, such as the community [10,87]. Indeed, shareholders are interested in knowing whether a firm adopts strategies coherent with their financial interests, such as tax planning. On the other hand, the community is interested in knowing what the impact of corporate activities is on CSR issues and whether the firm's tax approach is aligned with its commercial interests.

Second, this paper addresses matters that policymakers have to face. Research findings suggest that the involvement of gender diversity in corporate decision-making process allows a firm to plan ethical strategy, taking into account the interests of several groups of stakeholders. Therefore, governments and policymakers of the major countries have to promote gender diversity in corporate decision-making bodies and contribute to reaching the Sustainable Development Goals of the United Nations' Agenda 2030. Additionally, gender equality on corporate boards of directors helps to create a fair economy, to improve the quality of life of families and the community [16], and to improve global relations in accordance with the UNs' Principles for Responsible Investment (PRI) [88].

However, this study presents some limits. The population is only made up of firms listed on the Milano Stock Exchange, as these firms show the composition of the board of directors in their annual report published on their website. Furthermore, a homogeneous population is taken into account, as only non-financial listed firms that hold shares in at least one foreign subsidiary in countries other than Italy in the 2018 fiscal year are studied.

Future research could extend the population of this study, taking into account both non-financial firms and financial firms. Additionally, this empirical model could be tested on other countries' stock exchanges characterized by different legislation and cultures, exploring the different governance mechanisms in the European Union.

This research also reveals promising empirical research fields related to the corporate board attributes that could interest the study of tax aggressiveness and CSR. Future researchers could extend 
this study of listed firms to analyze the moderating role of characteristics such as board size, outside directors, and CEO duality on the relationship between tax aggressiveness and CSR. Additionally, because of possible corporate tax planning's reputational cost, it would be interesting to investigate the role of a corporate supervisory body such as auditor quality and audit committee.

Finally, future researchers could enrich this research field, adopting qualitative research methodologies such as case studies to acquire detailed information on internal and external factors that could influence a corporate decision-making process of adopting both tax planning and a CSR approach.

Author Contributions: This paper is the result of common reflections. A.V. wrote Sections 1 and 4; A.I. wrote Section 2; D.V. wrote Section 5; M.F. wrote Section 3. All authors have read and agreed to the published version of the manuscript.

Funding: Authors used their University funds for covering the costs to publish in open access.

Conflicts of Interest: The authors declare no conflict of interest.

\section{References}

1. Whait, R.B.; Christ, K.L.; Ortas, E.; Burritt, R.L. What do we know about tax aggressiveness and corporate social responsibility? An integrative review. J. Clean. Prod. 2018, 204, 542-552. [CrossRef]

2. Lanis, R.; Richardson, G. Outside directors, corporate social responsibility performance, and corporate tax aggressiveness: An empirical analysis. J. Account. Audit. Financ. 2018, 33, 228-251. [CrossRef]

3. Kubick, T.R.; Lockhart, G.B. Overconfidence, $\mathrm{CEO}$ awards, and corporate tax aggressiveness. J. Bus. Financ. Account. 2017, 44, 728-754. [CrossRef]

4. Dowling, G.R. The curious case of corporate tax avoidance: Is it socially irresponsible? J. Bus. Ethics 2014, 124, 173-184. [CrossRef]

5. Lanis, R.; Richardson, G. The effect of board of director composition on corporate tax aggressiveness. J. Account. Public Policy 2011, 30, 50-70. [CrossRef]

6. Bird, R.; Davis-Nozemack, K. Tax avoidance as a sustainability problem. J. Bus. Ethics 2018, 151, 1009-1025. [CrossRef]

7. Col, B.; Patel, S. Going to haven? Corporate social responsibility and tax avoidance. J. Bus. Ethics 2019, 154, 1033-1050. [CrossRef]

8. European Commission. Communication from the Commission to the European Parliament, the Council, the European Economic and Social Committee and the Committee of the Regions; Communication Number: COM/2011/0152 Final; European Commission: Brussels, Belgium, 2011.

9. Chatzoglou, P.; Chatzoudes, D.; Amarantou, V.; Aggelidis, V. Examining the antecedents and the effects of CSR implementation: An explanatory study. EuroMed J. Bus. 2017, 12, 189-206. [CrossRef]

10. Shams, S.R.; Vrontis, D.; Weber, Y.; Tsoukatos, E.; Galati, A. Stakeholder Engagement and Sustainability; Routledge: Abingdon, UK, 2019; ISBN 978-0-3672-1123-3.

11. Leonidou, E.; Christofi, M.; Vrontis, D.; Thrassou, A. An integrative framework of stakeholder engagement for innovation management and entrepreneurship development. J. Bus. Res. 2018, 1-14. [CrossRef]

12. Mdanat, M.F.; Shotar, M.; Samawi, G.; Mulot, J.; Arabiyat, T.S.; Alzyadat, M.A. Tax structure and economic growth in Jordan, 1980-2015. Euromed J. Bus. 2018, 13, 102-127. [CrossRef]

13. Freedman, J. Tax and corporate responsibility. Tax J. 2003, 695, 1-4.

14. Landolf, U. Tax and corporate responsibility. Int. Tax Rev. 2006, 29, 6-9.

15. Graham, J.R.; Hanlon, M.; Shevlin, T.; Shroff, N. Incentives for tax planning and avoidance: Evidence from the field. Account. Rev. 2014, 89, 991-1023. [CrossRef]

16. Rao, K.; Tilt, C. Board composition and corporate social responsibility: The role of diversity, gender, strategy and decision making. J. Bus. Ethics 2016, 138, 327-347. [CrossRef]

17. Kastlunger, B.; Dressler, S.G.; Kirchler, E.; Mittone, L.; Voracek, M. Sex differences in tax compliance: Differentiating between demographic sex, gender-role orientation, and prenatal masculinization (2D:4D). J. Econ. Psychol. 2010, 31, 542-552. [CrossRef]

18. Lanis, R.; Richardson, G.; Taylor, G. Board of director gender and corporate tax aggressiveness: An empirical analysis. J. Bus. Ethics 2017, 144, 577-596. [CrossRef] 
19. Bear, S.; Rahman, N.; Post, C. The impact of board diversity and gender composition on corporate social responsibility and firm reputation. J. Bus. Ethics 2010, 97, 207-221. [CrossRef]

20. Amorelli, M.F.; García-Sánchez, I.M. Critical mass of female directors, human capital, and stakeholder engagement by corporate social reporting. Corp. Soc. Responsib. Environ. Manag. 2020, 27, $204-221$. [CrossRef]

21. European Commission. Proposal for a Directive of the European Parliament and of the Council on Improving the Gender Balance among Non-Executive Directors of Companies Listed on Stock Exchanges and Related Measures; Communication Number: COM/2012/0614 Final-2012/0299 (COD); European Commission: Brussels, Belgium, 2012.

22. United Nations Department of Economic and Social Affairs. Transforming Our World: The 2030 Agenda for Sustainable Development; United Nations: New York, NY, USA, 2015.

23. Rao, K.; Tilt, C. Board diversity and CSR reporting: An Australian study. Meditari Account. Res. 2016, 24, 182-210. [CrossRef]

24. Binder, B. Does a high women quota in supervisory boards influence firm success? Euromed J. Bus. 2018, 13, 291-314. [CrossRef]

25. Hanlon, M.; Slemrod, J. What does tax aggressiveness signal? Evidence from stock price reactions to news about tax shelter involvement. J. Public Econ. 2009, 93, 126-141. [CrossRef]

26. Huseynov, F.; Klamm, B.K. Tax avoidance, tax management and corporate social responsibility. J. Corp. Financ. 2012, 18, 804-827. [CrossRef]

27. Mehrani, S.; Seyyedi, S.J. Investigating the relationship between tax avoidance and tax differences in companies listed on the Tehran stock exchange. Account. Audit. Res. 2014, 6, 50-75.

28. Desai, M.A.; Dharmapala, D. Corporate tax avoidance and high-powered incentives. J. Financ. Econ. 2006, 79, 145-179. [CrossRef]

29. Scholes, M.S.; Wolfson, M.A.; Erickson, M.; Maydew, E.; Shevlin, T. Taxes E business strategy; Prentice Hall: Upper Saddle River, NJ, USA, 2014.

30. Slemrod, J. The Economics of Corporate Tax Selfishness. Nat. Tax J. 2004, 57, 877-899. [CrossRef]

31. Friese, A.; Link, S.; Mayer, S. Taxation and corporate governance-The state of the art. In Tax and Corporate Governance; Schön, W., Ed.; Springer: Berlin/Heidelberg, Germany, 2008; pp. 357-425, ISBN 978-3-540-77275-0.

32. Lanis, R.; Richardson, G. Corporate social responsibility and tax aggressiveness: An empirical analysis. J. Account. Public Policy 2012, 31, 86-108. [CrossRef]

33. Sikka, P. Smoke and mirrors: Corporate social responsibility and tax avoidance. Account. Forum 2010, 34, 153-168. [CrossRef]

34. Hoi, C.K.; Wu, Q.; Zhang, H. Is corporate social responsibility (CSR) associated with tax avoidance? Evidence from irresponsible CSR activities. Account. Rev. 2013, 88, 2025-2059. [CrossRef]

35. European Commission. Communication from the Commission on the Social Agenda; Communication Number: COM/2005/0033 Final; European Commission: Brussels, Belgium, 2012.

36. Chrisman, J.J.; Chua, J.H.; Kellermanns, F.W.; Chang, E.P. Are family managers agents or stewards? An exploratory study in privately held family firms. J. Bus. Res. 2007, 60, 1030-1038. [CrossRef]

37. Barnea, A.; Rubin, A. Corporate social responsibility as a conflict between shareholders. J. Bus. Ethics 2010, 97, 71-86. [CrossRef]

38. Letza, S.; Sun, X.; Kirkbride, J. Shareholding versus stakeholding: A critical review of corporate governance. Corp. Gov. Int. Rev. 2004, 12, 242-262. [CrossRef]

39. Chauvey, J.N.; Giordano-Spring, S.; Cho, C.H.; Patten, D.M. The normativity and legitimacy of CSR disclosure: Evidence from France. J. Bus. Ethics 2015, 130, 789-803. [CrossRef]

40. Fernandez-Feijoo, B.; Romero, S.; Ruiz, S. Effect of stakeholders' pressure on transparency of sustainability reports within the GRI framework. J. Bus. Ethics 2014, 122, 53-63. [CrossRef]

41. Jo, H.; Harjoto, M.A. Corporate governance and firm value: The impact of corporate social responsibility. J. Bus. Ethics 2011, 103, 351-383. [CrossRef]

42. Branco, M.C.; Rodrigues, L.L. Corporate social responsibility and resource-based perspectives. J. Bus. Ethics 2006, 69, 111-132. [CrossRef]

43. Zhang, J.Q.; Zhu, H.; Ding, H.B. Board composition and corporate social responsibility: An empirical investigation in the post Sarbanes-Oxley era. J. Bus. Ethics 2013, 114, 381-392. [CrossRef] 
44. Cheng, E.C.; Courtenay, S.M. Board composition, regulatory regime and voluntary disclosure. Int. J. Account. 2006, 41, 262-289. [CrossRef]

45. Carroll, R.; Joulfaian, D. Taxes and corporate giving to charity. Public Financ. Rev. 2005, 33, 300-317. [CrossRef]

46. Preuss, L. Tax avoidance and corporate social responsibility: You can't do both, or can you? Corp. Gov. Int. J. Bus. Soc. 2010, 10, 365-374. [CrossRef]

47. Lanis, R.; Richardson, G. Is corporate social responsibility performance associated with tax avoidance? J. Bus. Ethics 2015, 127, 439-457. [CrossRef]

48. Muller, A.; Kolk, A. Responsible tax as corporate social responsibility: The case of multinational enterprises and effective tax in India. Bus. Soc. 2015, 54, 435-463. [CrossRef]

49. Jones, S.; Baker, M.; Lay, B.F. The relationship between CSR and tax avoidance: An international perspective. Aust. Tax Forum 2017, 32, 95. Available online: https://ssrn.com/abstract=2954291 (accessed on 22 January 2020).

50. Lanis, R.; Richardson, G. Corporate social responsibility and tax aggressiveness: A test of legitimacy theory. Account. Audit. Account. J. 2012, 26, 75-100. [CrossRef]

51. Gulzar, M.A.; Cherian, J.; Sial, M.; Badulescu, A.; Thu, P.; Badulescu, D.; Khuong, N. Does Corporate Social Responsibility Influence Corporate Tax Avoidance of Chinese Listed Companies? Sustainability 2018, 10, 4549. [CrossRef]

52. Marinova, J.; Plantenga, J.; Remery, C. Gender diversity and firm performance: Evidence from Dutch and Danish boardrooms. Int. J. Hum. Resour. Manag. 2016, 27, 1777-1790. [CrossRef]

53. Kılıç, M.; Kuzey, C. The effect of board gender diversity on firm performance: Evidence from Turkey. Gend. Manag. 2016, 31, 434-455. [CrossRef]

54. Reguera-Alvarado, N.; de Fuentes, P.; Laffarga, J. Does board gender diversity influence financial performance? Evidence from Spain. J. Bus. Ethics 2017, 141, 337-350. [CrossRef]

55. Nadeem, M.; Zaman, R.; Saleem, I. Boardroom gender diversity and corporate sustainability practices: Evidence from Australian Securities Exchange listed firms. J. Clean. Prod. 2017, 149, 874-885. [CrossRef]

56. Michelon, G.; Parbonetti, A. The effect of corporate governance on sustainability disclosure. J. Manag. Gov. 2012, 16, 477-509. [CrossRef]

57. Ahmadi, A.; Nakaa, N.; Bouri, A. Chief Executive Officer attributes, board structures, gender diversity and firm performance among French CAC 40 listed firms. Res. Int. Bus. Financ. 2018, 44, 218-226. [CrossRef]

58. Cabeza-García, L.; Fernández-Gago, R.; Nieto, M. Do board gender diversity and director typology impact CSR reporting? Eur. Manag. Rev. 2018, 15, 559-575. [CrossRef]

59. Lefort, F.; González, R. Hacia un mejor gobierno corporativo en Chile. Rev. Abante 2008, 11, 17-37.

60. Khaoula, A.; Ali, Z.M. Demographic Diversity in the board and corporate tax planning in American firms. Bus. Manag. Strategy 2012, 3, 72-86. [CrossRef]

61. Khan, H.U.Z. The effect of corporate governance elements on corporate social responsibility (CSR) reporting: Empirical evidence from private commercial banks of Bangladesh. Int. J. Law Manag. 2010, 52, 82-109. [CrossRef]

62. Khan, W.A.; Vieito, J.P. CEO gender and firm performance. J. Econ. Bus. 2013, 67, 55-66. [CrossRef]

63. Lam, K.C.; McGuinness, P.B.; Vieito, J.P. CEO gender, executive compensation and firm performance in Chinese-listed enterprises. Pac. Basin Financ. J. 2013, 21, 1136-1159. [CrossRef]

64. Dezsö, C.L.; Ross, D.G. Does female representation in top management improve firm performance? A panel data investigation. Strateg. Manag. J. 2012, 33, 1072-1089. [CrossRef]

65. Marquis, C.; Lee, M. Who is governing whom? Executives, governance, and the structure of generosity in large US firms. Strateg. Manag. J. 2013, 34, 483-497. [CrossRef]

66. Huang, J.; Kisgen, D.J. Gender and corporate finance: Are male executives overconfident relative to female executives? J. Financ. Econ. 2013, 108, 822-839. [CrossRef]

67. Manner, M.H. The impact of CEO characteristics on corporate social performance. J. Bus. Ethics 2010, 93, 53-72. [CrossRef]

68. Bowen, G.A. Document analysis as a qualitative research method. Qual. Res. J. 2009, 9, 27. [CrossRef]

69. Stock, J.H.; Watson, M.W. Introduction to Econometrics: Updated; Pearson Education: Harlow, UK, 2015; ISBN 978-1-292-07131-2. 
70. Cascino, S.; Pugliese, A.; Mussolino, D.; Sansone, C. The influence of family ownership on the quality of accounting information. Fam. Bus. Rev. 2010, 23, 246-265. [CrossRef]

71. Barontini, R.; Bozzi, S. Board compensation and ownership structure: Empirical evidence for Italian listed companies. J. Manag. Gov. 2011, 15, 59-89. [CrossRef]

72. Gul, F.A.; Leung, S. Board leadership, outside directors' expertise and voluntary corporate disclosures. J. Account. Public Policy 2004, 23, 351-379. [CrossRef]

73. Artiach, T.; Lee, D.D.; Nelson, D.; Walker, J.K. The determinants of corporate sustainability performance. Account. Financ. 2010, 50, 31-51. [CrossRef]

74. Haniffa, R.M.; Cooke, T.E. The impact of culture and governance on corporate social reporting. J. Account. Public Policy 2005, 24, 391-430. [CrossRef]

75. Brammer, S.; Millington, A.; Rayton, B. The contribution of corporate social responsibility to organizational commitment. Int. J. Hum. Resour. Manag. 2007, 18, 1701-1719. [CrossRef]

76. Stanny, E.; Ely, K. Corporate environmental disclosures about the effects of climate change. Corp. Soc. Responsib. Environ. Manag. 2008, 15, 338-348. [CrossRef]

77. Clarkson, P.M.; Li, Y.; Richardson, G.D.; Vasvari, F.P. Revisiting the relation between environmental performance and environmental disclosure: An empirical analysis. Account. Organ. Soc. 2008, 33, 303-327. [CrossRef]

78. Bouten, L.; Everaert, P.; Roberts, R.W. How a two-step approach discloses different determinants of voluntary social and environmental reporting. J. Bus. Financ. Account. 2012, 39, 567-605. [CrossRef]

79. Darus, F.; Arshad, R.; Othman, S.; Jusoff, K. Institutional Pressure and Ownership structure in Corporate Social Responsibility disclosure. Econ. Manag. J. 2013, 3, 1-28.

80. Dyreng, S.D.; Hanlon, M.; Maydew, E.L. Long-run corporate tax avoidance. Account. Rev. 2008, 83, 61-82. [CrossRef]

81. Minnick, K.; Noga, T. Do corporate governance characteristics influence tax management? J. Corp. Financ. 2010, 16, 703-718. [CrossRef]

82. Richardson, G.; Taylor, G.; Lanis, R. The impact of board of director oversight characteristics on corporate tax aggressiveness: An empirical analysis. J. Account. Public Policy 2013, 32, 68-88. [CrossRef]

83. Gnyawali, D.R.; Song, Y. Pursuit of rigor in research: Illustration from coopetition literature. Ind. Mark. Manag. 2016, 57, 12-22. [CrossRef]

84. Granado-Peiró, N.; López-Gracia, J. Corporate governance and capital structure: A Spanish study. Eur. Manag. Rev. 2017, 14, 33-45. [CrossRef]

85. Jové-Llopis, E.; Segarra-Blasco, A. Eco-innovation strategies: A panel data analysis of Spanish manufacturing firms. Bus. Strategy Environ. 2018, 27, 1209-1220. [CrossRef]

86. Hamilton, B.H.; Nickerson, J.A. Correcting for endogeneity in strategic management research. Strateg. Organ. 2003, 1, 51-78. [CrossRef]

87. Buhr, N.; Gray, R.; Milne, M.J. Histories, rationales, voluntary standards and future prospects for sustainability reporting: CSR, GRI, IIRC and beyond. In Sustainability Accounting and Accountability, 2nd ed.; Bebbington, J., Unerman, J., O’Dwyer, B., Eds.; Routledge: Abingdon, UK, 2014; pp. 69-89, ISBN 978-0-415-69558-9.

88. UN PRI. What is responsible investment? 2019. Available online: https://www.unpri.org/download?ac $=6998$ (accessed on 25 January 2020).

(C) 2020 by the authors. Licensee MDPI, Basel, Switzerland. This article is an open access article distributed under the terms and conditions of the Creative Commons Attribution (CC BY) license (http://creativecommons.org/licenses/by/4.0/). 